\title{
MOLECULAR GEOMETRY AND STRUCTURE-PROPERTY RELATIONSHIPS FOR 1,2-DITHIOLE-3-THIONE DERIVATIVES
}

\author{
BELAIDI S. ${ }^{*}$, MELKEMI N. ${ }^{1}$ AND BOUZIDI D. ${ }^{2}$ \\ ${ }^{1}$ Group of Computational and Pharmaceutical Chemistry, LMCE Laboratory, Department of Chemistry, Faculty of Sciences, University of Bis- \\ kra, 07000, Biskra, Algeria. \\ 2Scientific Approach Institute, Waterman Ave Suite 5 1264, San Bernardino CA 92408, USA. \\ *Corresponding Author: Email-salah_belaidi@hotmail.com
}

\section{Received: November 28, 2012; Accepted: December 12, 2012}

\begin{abstract}
Molecular geometry, electronic structure, effect of the substitution and structure physical-chemical property relationship for 1,2dithiole-3-thione derivatives, have been studied by molecular mechanics, PM3, Ab initio, DFT and QSAR method. In the present work, the calculated values, namely net charges, bond lengths, dipole moments, electron-affinities, heats of formation and QSAR properties, are reported and discussed in terms of the biological activity of 1,2-dithiole-3-thione derivatives.
\end{abstract}

Keywords- 1,2-dithiole-3-thione, QSAR Properties, Structure, Ab intio, DFT

Citation: Belaidi S., Melkemi N. and Bouzidi D. (2012) Molecular Geometry and Structure-Property Relationships for 1,2-Dithiole-3-Thione Derivatives. International Journal of Chemical Research, ISSN: 0975-3699 \& E-ISSN: 0975-9131, Volume 4, Issue 2, pp.-134-139.

Copyright: Copyright@2012 Belaidi S., et al. This is an open-access article distributed under the terms of the Creative Commons Attribution License, which permits unrestricted use, distribution and reproduction in any medium, provided the original author and source are credited.

\section{Introduction}

D3T (3H-1,2-dithiole-3-thione) and its derivatives have attracted considerable attention for several years because of their significant biological activities. For, instance; D3T is known to enhance the detoxification of environmental carcinogens and elicit other protective effects by inducing phase 2 and antioxidative enzymes [1]. A number of derivatives of 1,2-dithiole-3-thione have been shown in induce phase II enzymes, and one compound of this type, Olipraz (4-methyl-5-pyrazinyl-3H-1,2-dithiole-3-thione) has been extensively studied [2-6]. Olipraz possesses remarkable activity to inhibit HIV -1 (AIDES) virus replication by irreversibly binding the viral reserve transcriptase enzyme [7].

Other derivatives have been found to be fungitoxic and bacteriostatic. The wide spectrum of biological activities displayed by such compounds has been urging chemists to develop new methods for synthesis of various substituted derivatives [8-10].

The ability of a drug to penetrate various biological membranes, tissues and barriers is a primary factor in controlling the interaction of drugs with biological systems. In quantitative structure activity relationship models (QSAR) in which physicochemical parameters of drugs are correlated with biological activities, lipophilicity (partition Coefficient) has a major role. Other important parameters are polarizability, electronic and steric parameters, molecular weight, geometry, conformational entropies etc.

The present work reports $a b$ initio and density functional results of molecular properties of 1,2-dithiole-3-thione. We also studied some of 1,2-dithiole-3-thione derivatives by DFT method. Finally, we have studied some of QSAR proprieties of a series of these compounds.

\section{Material and Methods}

Initial calculations were optimized using HyperChem 8.03 software [11]. The geometries of 1,2-dithiole-3-thione and its derivatives; were first fully optimized by molecular mechanics, with $\mathrm{MM}+$ forcefield $(\mathrm{rms}=0.001 \mathrm{Kcal} / \mathrm{A})$. Further, geometries were fully reoptimized by using PM3 method [12].

In the next step, a parallel study has been made using Gaussian 03 program package [13], at various computational levels, HF/6$311++G(d, p)$ and B3LYP/6-311++G(d,p).

The calculation of QSAR properties is performed by the module (QSAR Properties, version 8.0). QSAR Properties is a module that, together with HyperChem, allows several properties commonly used in QSAR studies to be calculated. The calculations are empirical, so, generally, are fast. The calculated results have been reported in the present work.

\section{Results and Discussion}

Geometric and Electronic Structure of 3H-1,2-dithiole-3-thione and 1,2-dithiole-3-thione Systems

The optimized geometrical parameters of $3 \mathrm{H}-1,2$-dithiole-3-thione by ab initio/HF and DFT method listed in [Table-1] are in accordance with numbering scheme given in [Fig-1].

The efficiency of theoretical methods may be assessed by comparison with experimental results [14]. Present results concerning bond length values, valence angles and dihedral angles for $3 \mathrm{H}-1,2-$ dithiole-3-thione [Table-1] and charge densities [Table-2].

We can note a good correlation between calculated and experimental values for geometric parameters and charge densities calculated by ab initio are similar to those calculated by DFT method. 
The geometry of the 1,2-dithiole-3-thione is planar. The dihedral angles of cycle of this molecule vary between 0.00 and 0.01 degree.

Table 1- Calculated values of bond lengths, valence angles and dihedral angles of $3 \mathrm{H}-1,2-$ dithiole-3-thione

\begin{tabular}{|c|c|c|c|c|}
\hline & Parameters & $\begin{array}{l}\text { EXP. } \\
{[14]}\end{array}$ & $\begin{array}{c}\text { Ab initio/HF } \\
6-311++G(d, p)\end{array}$ & $\begin{array}{c}\text { DFT/B3LYP } \\
6-311++G(d, p)\end{array}$ \\
\hline \multirow{7}{*}{$\begin{array}{l}\text { Bond length } \\
\text { (Angstrom) }\end{array}$} & S6-C3 & 1.668 & 1.632 & 1.653 \\
\hline & S2-S1 & 2.05 & 2.087 & 2.127 \\
\hline & S2-C3 & 1.769 & 1.75 & 1.772 \\
\hline & C3-C4 & 1.376 & 1.45 & 1.439 \\
\hline & S1-C5 & 1.693 & 1.733 & 1.736 \\
\hline & C5-C4 & 1.338 & 1.332 & 1.352 \\
\hline & S1-S2-C3 & 96.8 & 96.8 & 96.7 \\
\hline \multirow{6}{*}{$\begin{array}{l}\text { Valence angle } \\
\text { (degree) }\end{array}$} & S2-S1-C5 & 93 & 93 & 92.4 \\
\hline & S1-C5-C4 & 119 & 119.4 & 119.6 \\
\hline & S6-C3-C4 & 135.5 & 126.5 & 128.6 \\
\hline & S2-C3-C4 & 111.1 & 112.3 & 111.9 \\
\hline & S6-C3-S2 & 113.4 & 121 & 119.4 \\
\hline & C5-C4-C3 & 120 & 118.2 & 119.2 \\
\hline \multirow{7}{*}{$\begin{array}{l}\text { Dihedral angle } \\
\text { (degree) }\end{array}$} & C3-S2-S1-C5 & - & 0 & 0.01 \\
\hline & S1-S2-C3-S6 & - & 179.98 & 179.98 \\
\hline & S1-S2-C3-C4 & - & 0 & 0 \\
\hline & S2-S1-C5-C4 & - & 0 & 0.01 \\
\hline & S1-C5-C4-C3 & - & 0.01 & 0.01 \\
\hline & S6-C3-C4-C5 & - & 179.98 & 179.99 \\
\hline & S2-C3-C4-C5 & - & 0.01 & 0 \\
\hline
\end{tabular}

Table 2- Mulliken charges of 3-H-1,2-dithiole-3-thione

\begin{tabular}{lcc} 
Atoms & Ab initio/HF 6-311++C(d,p) & DFT/B3LYP 6-311G++(d,p) \\
S1 & -0.135 & -0.111 \\
S2 & -0.203 & -0.18 \\
S6 & -0.658 & -0.53 \\
C3 & 0.951 & 0.826 \\
C4 & -0.73 & -0.729 \\
C5 & 0.24 & 0.256 \\
\hline
\end{tabular}

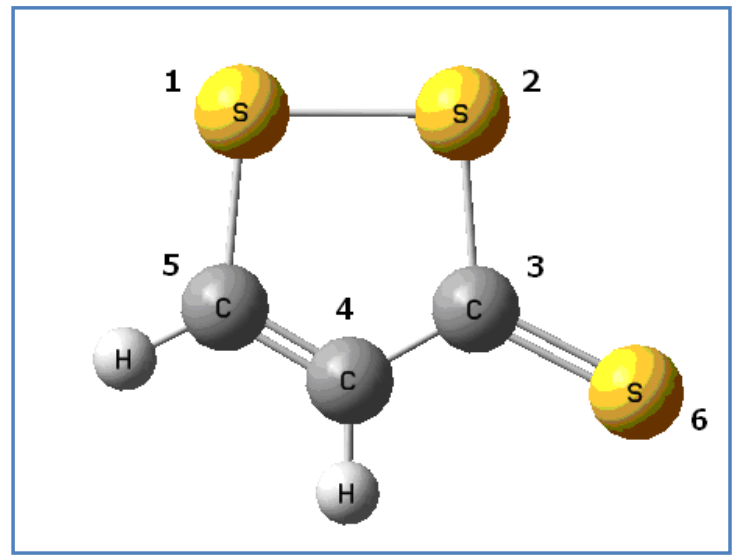

Fig. 1- 3D conformation of 3H-1,2-dithiole-3-thione

(GaussView 3.09)

The calculated values of (methyl, ethyl) substituted 1,2-dithiole-3thione and (cyanide, chloride) substituted 1,2-dithiole-3-thione [Fig-2] are given in [Table-3], [Table-4], [Table-5]. In [Table-3], heat of formation, dipole moment, HOMO (highest occupied molecular orbital), LUMO (lowest unoccupied molecular orbital) and their difference $(\Delta \mathrm{E})$ are reported for 1,2-dithiole-3-thione and its derivatives. In [Table-4], [Table-5] Net atomic charges are also reported.

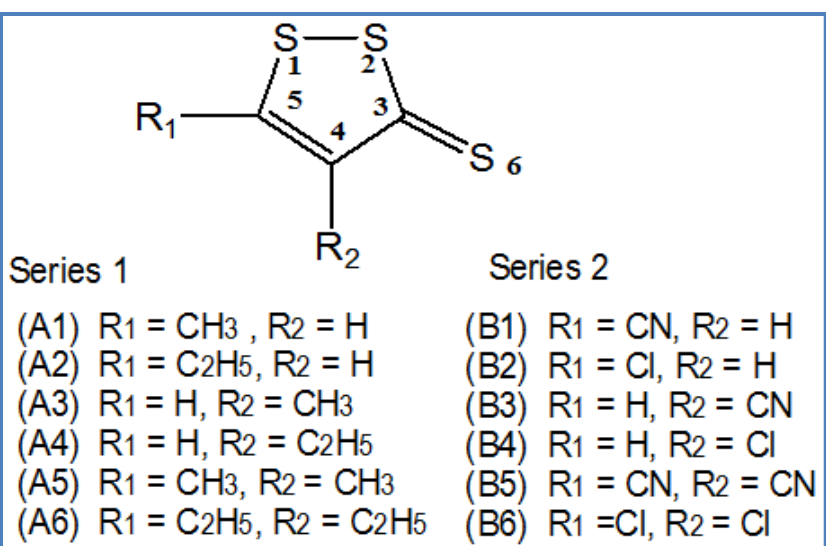

Fig. 2- Scheme of 1,2-dithiole-3-thione systems.

The heat of formation is decreased approximately 8 and $12 \mathrm{kcal} / \mathrm{mol}$ at each addition of methyl and ethyl groups respectively.

The negative atomic charge on sulfur atoms is increased considerably for methyl and ethyl derivatives, except for compounds A3 and A4 for S2 atom [Table-4]. In the mono-substituted alkyl group category, the 4 -ethyl-1,2-dithiole-3-thione (compound A2) showing maximum positive charge on 3rd position carbon (1.69) which leads to nucleophilic substitution [Table-4]. This is further supported by the smaller HOMOLUMO energy gap (0.133) [Table-3] which depicts the chemical reactivity of the compound; higher is the HOMO-LUMO energy gap, lesser is the flow of electrons to the higher energy state, making the molecule hard and less reactive. On the other hand in smaller HOMOLUMO gap, there is easy flow of electrons to the higher energy state making it softer and more reactive (HSAB principle: hard and soft acids and bases). Hard bases have highest-occupied molecular orbitals (HOMO) of low energy, and hard acids have lowest-unoccupied molecular orbitals (LUMO) of high energy [15].

In the case of dimethyl and diethyl substituted of dithiolethione the C-3 position (compound A5) shows maximum charge (2.01), smaller $\mathrm{HO}-$ MO-LUMO energy gap (0.133) [Table-3], [Table-4] which leads to preferential site of nucleophilic attack. We also note that the methyl and ethyl substituent (donor effect) has the effect of increasing the energy of the HOMO, with little change in the LUMO [Table-3].

In the present work, we have studied cyanide and Chloride substituted 1,2-dithiole-3-thiones along the same line of methyl and ethyl substituted dithiolethiones for a comparative study.

The heat of formation is decreased approximately $3 \mathrm{Kcal} / \mathrm{mol}$, for each addition of Chloride atom and is increased approximately $41 \mathrm{Kcal} / \mathrm{mol}$ for each addition of cyanide group.

In mono-substituted cyanide and chloride derivatives, 5-cyano-1,2dithiole-3-thione (compound B3) is predicted to be more chemically reactive than 4-Cyano-1,2-dithiole-3-thione, 4-Chloro-1,2-dithiole-3thione and 5-Chloro-1,2-dithiole-3-thione on the basis of least HOMOLUMO energy gap (0.119) [Table-3].

The carbon C-5 in 5-cyano-1,2-dithiole-3-thione shows maximum positive charge (1.37) leading to favored site for nucleophilic attack [Table-5]. In disubstituted cyanide and chloride derivatives, dicyano1,2-dithiole-3-thione (compound B5) is more reactive than dichloro-1,2 -dithiole-3-thione (compound B6), this is due to smaller HOMO-LUMO energy gap (0.113) [Table-3].

The compound B5 is predicted to be the most reactive with smaller HOMO-LUMO energy gap of all 1,2-dithiole-3-thione systems. We 
note also that the cyanide and chloride substituent (attractor effect) lowers the energies of $\mathrm{HOMO}$ and LUMO. His influence on the energy of the LUMO is more important [Table-3].

The presence of an attractor group in the C5 position causes the decrease in dipole moment. Hence, we can conclude these compounds takes part in the conformation in which the thione and electro-attractor groups are antiparallel and are found in the plane of dithiole [Table-3]. The compound $\mathrm{B} 1$ shows the maximum dipole moment value. It would originate from a resonance effect, involving a donor effect from the dithiole nucleus toward electroattractive group in position 4.
The contour plots of the m-like frontier orbital's for the ground state of compound B1 are shown in [Fig-3], including the highest occupied molecular orbital (HOMO) and lowest unoccupied molecular orbital (LUMO). From the plots, one can find that the HOMO mainly concentrates on S3 and the dithiolethione ring with some delocalization along S1-C5 and S2-C3-C4, whereas, the LUMO distributes over the whole molecule with some delocalization along C3-C4-(C-cyano). These further demonstrate that there exists the delocalization of the conjugated m-electron system in the molecule of compound B1.

Table 3- Energies of 1,2-dithiole-3-thione derivatives

\begin{tabular}{|c|c|c|c|c|c|c|}
\hline Compound & System & Heat of formation (kcal/mol) & -HOMO (a.u.) & -LUMO (a.u.) & $\Delta \mathrm{E}($ a.u. $)$ & $\mu(\mathrm{D})$ \\
\hline D3T & 1,2-dithiole-3-thione & 67.243 & 0.235 & 0.101 & 0.134 & 4.103 \\
\hline A1 & 4-Methyl-1,2-dithiole-3-thione & 59.132 & 0.231 & 0.096 & 0.135 & 3.991 \\
\hline A2 & 4-Ethyl-1,2-dithiole-3-thione & 55.149 & 0.23 & 0.097 & 0.133 & 3.949 \\
\hline A3 & 5-Methyl-1,2-dithiole-3-thione & 59.536 & 0.23 & 0.094 & 0.136 & 4.911 \\
\hline A4 & 5-Ethyl-1,2-dithiole 3-thione & 55.149 & 0.228 & 0.093 & 0.135 & 5.116 \\
\hline A5 & Dimethyl-1,2-dithiole-3-thione & 52.403 & 0.225 & 0.092 & 0.133 & 4.829 \\
\hline A6 & Diethyl-1,2-dithiole-3-thione & 41.752 & 0.224 & 0.09 & 0.134 & 4.916 \\
\hline B1 & 4- Cyano-1,2-dithiole-3-thione & 108.229 & 0.253 & 0.122 & 0.131 & 5.589 \\
\hline B2 & 4-Chloro-1,2-dithiole-3-thione & 63.542 & 0.241 & 0.109 & 0.132 & 3.948 \\
\hline B3 & 5- Cyano-1,2-dithiole-3-thione & 109.128 & 0.255 & 0.136 & 0.119 & 1.774 \\
\hline B4 & 5-Chloro-1,2-dithiole-3-thione & 64.902 & 0.242 & 0.108 & 0.134 & 2.987 \\
\hline B5 & Dicyano-1,2-dithiole-3-thione & 152.242 & 0.269 & 0.156 & 0.113 & 5.257 \\
\hline B6 & Dichloro-1,2-dithiole-3-thione & 61.295 & 0.246 & 0.114 & 0.132 & 3.104 \\
\hline
\end{tabular}

Heat of formation by $P M 3, \triangle E$ and $\mu$ by DFT

Table 4- Mulliken charges of 1,2-dithiole-3-thione and derivatives (series 1)

\begin{tabular}{lccccccc} 
Compound & D3T & A1 & A2 & A3 & A4 & A5 & A6 \\
\hline S1 & -0.111 & -0.249 & -0.341 & -0.456 & -0.486 & -0.772 & -0.682 \\
S2 & -0.18 & -508 & -0.467 & 0.001 & 0.017 & -0.283 & -0.313 \\
S6 & -0.53 & -0.607 & -0.55 & -0.641 & -0.648 & -0.722 & -0.651 \\
C3 & 0.826 & 1.603 & 1.686 & 0.508 & 0.478 & 2.008 & 1.927 \\
C4 & -0.729 & -1.409 & -1.477 & -0.256 & -0.22 & -1.693 & -2.057 \\
C5 & 0.256 & 0.882 & 0.993 & 0.503 & 0.52 & 1.441 & 1.938 \\
C-methyl 4 & - & -0.491 & - & - & - & -0.875 & - \\
C-methyl 5 & - & - & - & -0.337 & - & -0.08 & - \\
C-1'-ethyl 4 & - & - & -0.284 & - & - & - & -0.428 \\
C-2'-ethyl 4 & - & - & -0.61 & - & - & - & -0.638 \\
C-1'-ethyl 5 & - & - & - & - & -0.106 & - & -0.003 \\
C-2'-ethyl 5 & - & - & - & - & -504 & - & -0.601 \\
\hline
\end{tabular}

Net charge calculated by DFT

Table 5- Mulliken charges of 1,2-dithiole-3-thione and derivatives (series 2)

\begin{tabular}{lccccccc} 
Compound & D3T & B1 & B2 & B3 & B4 & B5 & B6 \\
S1 & -0.111 & -0.186 & -0.165 & -0.284 & -0.225 & -0.596 & -0.328 \\
S2 & -0.18 & -0.368 & -0.26 & -0.033 & -0.103 & -0.194 & -0.214 \\
S6 & -0.53 & -0.542 & -0.563 & -0.567 & -0.602 & -0.566 & -0.591 \\
C3 & 0.826 & 0.733 & 0.616 & 0.484 & 0.249 & 1.877 & 0.488 \\
C4 & -0.729 & 0.046 & -0.318 & -0.089 & -0.062 & -0.216 & -0.615 \\
C5 & 0.256 & 1.04 & -0.078 & 1.367 & -0.026 & 2.207 & 0.115 \\
C-cyano 4 & - & -0.928 & - & - & - & -2.041 & - \\
N-cyano 4 & - & -0.155 & - & - & - & -0.096 & - \\
C-cyano 5 & - & - & - & -0.954 & - & -0.277 & - \\
N-cyano 5 & - & - & - & -0.126 & - & -0.099 & - \\
Chloro 4 & - & - & 0.46 & - & - & - & 0.544 \\
Chloro 5 & - & - & - & - & 0.537 & - & 0.602 \\
\hline
\end{tabular}

Net charge calculated by DFT

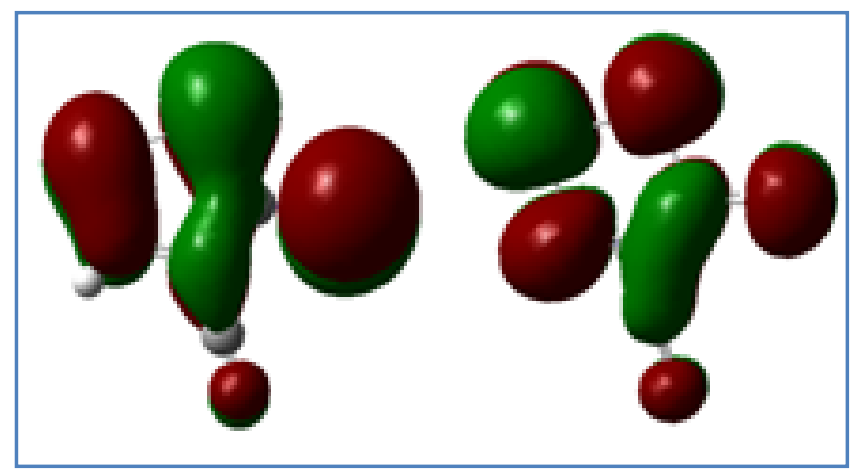

Fig. 3- Schematic drawings of the HOMO and LUMO of compound B1

\section{Study of Structure-Property Relationships for 1-2-dithiole-3- thione Derivatives}

We have studied six physical and chemical proprieties of a series of nineteen dithiolethione derivatives using HyperChem software. For example, in [Fig-4], the favored conformation in 3D of the compound 11 . We will continue this work in the future by a quantitative calculation. QSAR proprieties are, van der Waals surface molecular volume, octanol-water partition coefficient $(\log P)$, polarizability, solvent-accessible surface bounded molecular volume and molecular mass (M). Calculation of log $P$ is carried out using atomic parameters derived by Viswanadhan and coworkers [16]. Log $P$ is one criterion used in medicinal chemistry to assess the drug likeness of a given molecule, and used to calculate lipophilic efficiency, a function of potency and $\log P$ that evaluate the quality of research compounds. For a given compound lipophilic efficiency is defined as the $\mathrm{plC}_{50}$ (or $\mathrm{pEC}_{50}$ ) of interest minus the $\log \mathrm{P}$ of the compound. 
Computation of molar refractivity was made via the same method as $\log$ P. Ghose and Crippen presented atomic contributions to the refractivity [17].

Solvent-accessible surface bounded molecular volume and van der Waals-surface-bounded molecular volume calculations are based on a grid method derived by Bodor et al. [18], using the atomic radii of Gavezotti [19]. Polarizability was estimated from an additivity scheme given by Miller with a $3 \%$ in precision for the calculation [20], where different increments are associated with different atom types.

Hydration energy is a key factor determining the stability of different molecular conformations in water solutions [21]. The calculation is based on exposed surface area as computed by the approximate method (above), weighted by atom type.

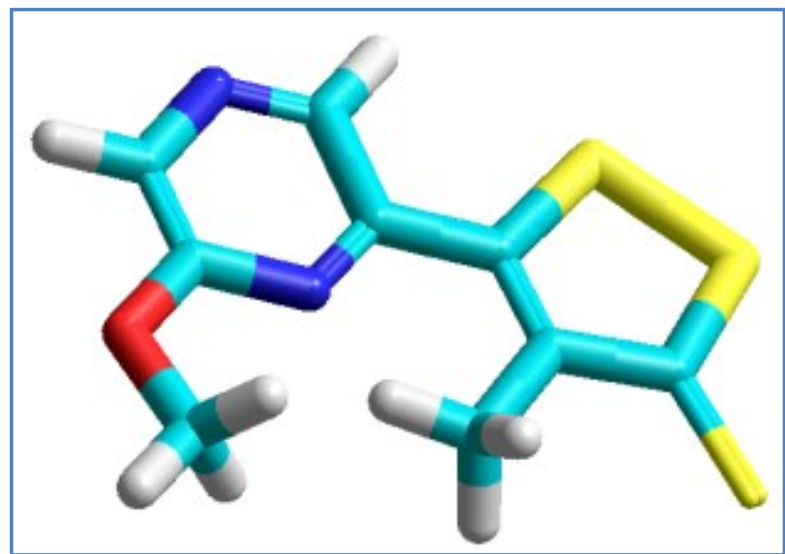

Fig. 4- 3D conformation of compound 11 (HyperChem 8.03)

\section{Structural Comparison of the Dithiolethione Derivatives}

Based on our conclusions on the effect of substitution on the 1,2 dithiole-3-thione molecules. We chose a series of dithiolethione derivatives; some of them have a biological activity [22-32]. This series of 1,2-dithiole-3-thione derivatives are given in [Table-6]. Initially, we performed a structural comparison of this series [Fig-5]. We used molecular mechanics, with $\mathrm{MM}+$ force-field to calculate the stable conformations of this series. In a window of $2 \mathrm{kcal} / \mathrm{mol}$, only one favored conformations is found, for each structure. These molecules have a weak conformational flexibility, with regard to the other macrocycles of macrolide type [33-39].

\section{Table 6- Dithiolethione derivatives}

\begin{tabular}{|llc}
\hline Compound Dithiolethione & Reference \\
\hline 1 & 4-methyl-5-pyrazinyl-3H-1,2-dithiole-3-thione (oltipraz) & {$[22,23]$} \\
2 & 5-(4-hydroxyphenyl)-3H-1,2-dithiole-3-thione & {$[24]$} \\
3 & 4-Chloro-5-methyl-3H-1,2-dithiole-3-thione & {$[25]$} \\
4 & 5,6-dihydro-4H-cyclopenta-1,2-dithiole-3(4H)-thione & {$[26,27]$} \\
5 & 4-phenyl-3H-1,2-dithiole-3-thione & {$[24]$} \\
6 & 5-(4-methoxyphenyl)-3H-1,2-dithiole-3-thione & {$[28,29]$} \\
7 & 5-methyl-3H-1,2,-dithiole-3-thione & {$[30]$} \\
8 & 5-propylthio-3H-1,2-dithiole-3-thione & {$[31]$} \\
& (Z)-5-fluoro-2-methyl-1-[4-(methylsulfinyl)phenyl]- & \\
9 & methylene]-1H-indene-3-acetic acid 4-(5-thioxo-5H-[1,2] & {$[24]$} \\
& dithiol-3-yl)-phenyl ester (S-sulindac) & \\
10 & 2-[(2,6-dichlorophenyl)amino]benzeneacetic acid 4-(3H- & {$[24]$} \\
11 & 1,2,dithiol-3-thione-5-yl) phenyl ester (S-diclofenac) & {$[26,32]$} \\
12 & 5-(6-methoxypyrzinyl)-4-methyl-1,2-dithiole-3-thione & {$[26,32]$} \\
\hline
\end{tabular}

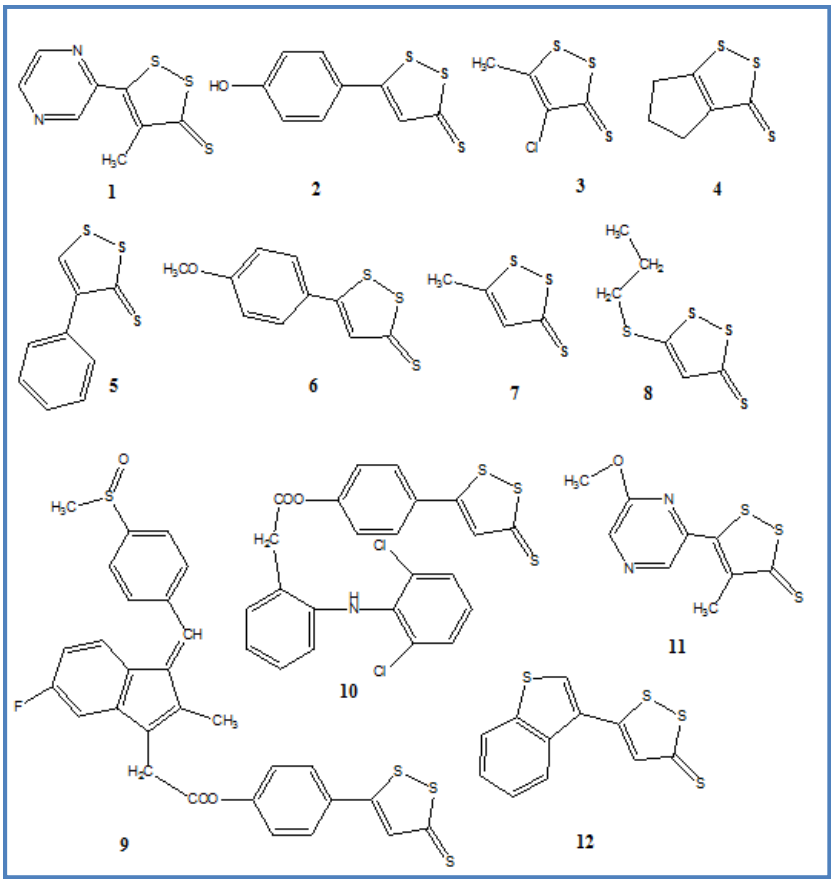

Fig. 5- Chemical structures of the dithiolethiones

\section{Structure Property Relationships}

Lipophilicity is a property that has a major effect on solubility, absorption, distribution, metabolism, and excretion properties as well as pharmacological activity. Lipophilicity has been studied and applied as an important drug property for decades. It can be quickly measured or calculated. Lipophilicity has been correlated to many other properties, such as bioavailability, storage in tissues, permeability, volume of distribution, toxicity, plasma protein binding and enzyme receptor binding $[40,41]$.

Polarizability values are generally proportional to the values of surfaces and of volumes, the decreasing order of polarizability for these studied dithiolethiones is: $9,10,12,11,6,2,1,5,8,4,3$, and 7 [Table-7]. The order of polarizability is approximately the same one for volume and surface. This also is explained by the relation between polarizability and volume, for the relativity non polar molecules. They are directly linked, for the centers of gravity of negative and positive charges in the absence of external fields to coincide, and the dipole moment of the molecule is zero.

The polarizability of a molecule depends only on its volume, which means that the thermal agitation of non polar molecules does not have any influence on the appearance of dipole moments in these molecules.

On the other hand, for the polar molecules, the polarizability of the molecule does not depend solely on volume but also depends on other factors such as the temperature because of the presence of the permanent dipole [42].

Surface and distribution volume of these molecules are definitely higher than those of more polar molecules like the lipopeptides or beta-lactams. For example, Deleu et al. used Tammo software on the surfactins $\mathrm{C} 13, \mathrm{C} 14$ and $\mathrm{C} 15$ having cores similar to the macrolides [43]. They found that their surfaces vary from 129 to $157 \AA^{2}$ [44], contrarily for these dithiolethiones, surfaces vary from 259 to $510 \AA^{2}$. These dithiolethiones has a great variation of distribution volume, in particular compound 9 and compound 10 which have respective volumes: 1275.82 and $1138.71 \AA^{3}$ [Table-7]. 
The most important hydration energy in the absolute value, is that of the compound $2(12.57 \mathrm{kcal} / \mathrm{mol})$ and the weakest is that of compound 4 (3.14 kcal/mol) [Table-7]. Indeed, in the biological environments the polar molecules are surrounded by water molecules. They are established hydrogen bonds between a water molecule and these molecules. The donor sites of the proton interact with the oxygen atom of water and the acceptor sites of the proton interact with the hydrogen atom. The first corresponds to the complex with the strongest hydrogen bond. These hydrated molecules are dehydrated at least partially before and at the time of their interaction. These interactions of weak energy, which we observe in particular between messengers and receivers, are generally reversible [45]. Compound 2 has a site donor of the proton $(\mathrm{OH})$ and two acceptor sites of the proton ( $O$ in hydroxyl group and $S$ of group $S=0$ ). But, in the other sulfur atoms, the acceptor effect is greatly reduced, because of the mesomeric effect. On the other hand, the compound 4 does not possess any donor site but posses one acceptor site of the proton ( $S$ of group $S=0$ on the principal cycle). This property supports the first compound, not only by fixing the receiver, but also activates it. It is thus about an agonist. It has as a consequence a better distribution in fabrics.

All $(\log P)$ of studied molecules have optimal values. For good oral bioavailability, the $\log P$ must be greater than zero and less than 3 $(0<\log P<3)$. For $\log P$ too high, the drug has low solubility and a $\log P$ too low; the drug has difficulty penetrating the lipid membranes [40].

Compound 9 presents the low coefficient of division (0.21) and comes after compound $12(0.61)$. These molecules possess a good solubility. When the coefficient of division is rather low, it has as a consequence a better gastric tolerance. Compound 8, 10 and 5 which have, respectively, higher values $3.08,1.96$ and 1.96; these molecules are the most absorbent products and have important capacities to be dependent on plasmatic proteins.

Table 7- QSAR proprieties for dithiolethione derivatives

\begin{tabular}{|c|c|c|c|c|c|c|}
\hline Dithiolethione & Molecular Volume $\left(\AA^{3}\right)$ & Molecular Surface $\left(\AA^{2}\right)$ & Molecular Mass (uma) & Partition coefficient $(\log P)$ & Hydration energy (kcal/mol) & Polarizability $\left(\AA^{3}\right)$ \\
\hline 1 & 574.51 & 295.59 & 226.33 & 1 & -6.54 & 24.64 \\
\hline 2 & 583.22 & 317.49 & 226.33 & 0.9 & -12.57 & 24.86 \\
\hline 3 & 451.7 & 295.99 & 182.7 & 1.15 & -3.74 & 18.32 \\
\hline 4 & 478.29 & 258.92 & 174.29 & 1.49 & -3.14 & 19.29 \\
\hline 5 & 553.01 & 291.92 & 210.33 & 1.96 & -5.66 & 24.22 \\
\hline 6 & 640.79 & 362.45 & 240.35 & 0.93 & -7.39 & 26.69 \\
\hline 7 & 417.31 & 271.64 & 148.26 & 1.25 & -4.09 & 16.39 \\
\hline 8 & 587.62 & 387.42 & 208.37 & 3.08 & -4.1 & 23.06 \\
\hline 9 & 1275.82 & 510.35 & 564.72 & 0.21 & -7.71 & 58.26 \\
\hline 10 & 1138.71 & 458.47 & 504.46 & 1.96 & -8.68 & 54.9 \\
\hline 11 & 648.24 & 347.12 & 256.36 & 1.7 & -8.28 & 27.11 \\
\hline 12 & 654.33 & 322.87 & 266.41 & 0.61 & -6.75 & 29.92 \\
\hline
\end{tabular}

\section{Conclusions}

The present study provides a discussion of several molecular properties of $3 \mathrm{H}$-1,2-dithiole-3-thione based on ab initio and density functional theory calculations. The PM3, DFT and ab initio method can be used quite satisfactorily in predicting the chemical reactivity of the molecules and the effect of substitution of either donor or acceptor electron. Our results are closer to experimental data than those reported in previous calculations The study of the substitution on the core base dithiolethione shows an influence of the nature of the substituted donor groups (methyl, ethyl) and acceptor groups (cyanide, chloride) on energy and electronic properties of the base molecule.

In the substituted cyanide group, dicyano-1,2-dithiole-3-thione is predicted to be the most reactive with least HOMO-LUMO energy gap of all ditiolethione derivatives.

The presence of an attractor group in the $C 5$ position causes the decrease in dipole moment, but the presence of a cyanide group in the $\mathrm{C} 4$ position induces an increase in the dipole moment.

The 5-propylthio-3H-1,2-dithiole-3-thione, S-diclofenac and 5,6dihydro-4H-cyclopenta-1,2-dithiole-3(4H)-thione, presents the same higher coefficient of division. These lipophilic compounds penetrate in various membranes, including cellular membranes as well as tissues with high lipoid content, to arrive at the receptor site.

\section{References}

[1] Karuri A.R., Huang Y., Bodreddigari S., Sutter C.H., Roebuck
B.D., Kensler T.W., Sutter T.R. (2006) Journal of Pharmacoogyl and Experimental Therapeutics, 317, 61-67

[2] Ansher S.S., Dolan P., Bueding E. (1983) Hepatology 3, 932935.

[3] Bueding E., Dolan P., Leroy J.P. (1982) Research Communications in Chemical Pathology \& Pharmacology, 37, 293-303.

[4] Kensler T.W., Groopman J.D., Sutter T.R., Curphey T.J., Roebuck B.D. (1999) Chemical Research in Toxicology, 12, 113-126.

[5] Kwak M.K., Ramos-Gomez M., Wakabayashi N., Kensler T.W. (2004) Methods in Enzymology, 382, 414-423.

[6] Clapper M.L., Everley L.C., Strobel L.A., Townsend A.J., Engstrom P.F. (1994) Molecular Pharmacology, 45, 469-474.

[7] Prochaska H.J., Yeh Y., Baron P., Polsky B. (1993) Proceedings of the National Academy of Sciences of the USA, 90, 3953-3957.

[8] Landis P.S. (1965) Chemical Reviews, 65 (2), 237-245.

[9] Pedersen C.T. (1982) Advances in Heterocyclic Chemistry, 31, 63-113.

[10]Yuesheng Z., Rex M. (2008) Molecular Cancer Therapeutics, 7, 3470-3479.

[11]Hypercube, Inc. (2007) HyperChem Molecular Modeling System, USA.

[12]Stewart J.J.P. (1989) Journal of Computational Chemistry, 10 (2), 221-264.

[13]Frisch M.J., Trucks G.W., Schlegel H.B., Scuseria G.E., Robb 
M.A., Cheeseman J.R., Montgomery Jr. J.A., Vreven T., Kudin K.N., Burant J.C., Millam J.M., lyengar S.S., Tomasi J., Barone V., Mennucci B., Cossi M., Scalmani G., Rega N., Petersson G. A., Nakatsuji H., Hada M., Ehara M., Toyota K., Fukuda R., Hasegawa J., Ishida M., Nakajima T., Honda Y., Kitao O., Nakai H., Klene M., Li X., Knox J.E., Hratchian H.P., Cross J.B., Bakken V., Adamo C., Jaramillo J., Gomperts R., Stratmann R.E., Yazyev O., Austin A.J., Cammi R., Pomelli C., Ochterski J.W., Ayala P.Y., Morokuma K., Voth G.A., Salvador P., Dannenberg J.J., Zakrzewski V.G., Dapprich S., Daniels A.D., Strain M.C., Farkas O., Malick D.K., Rabuck A.D., Raghavachari K., Foresman J.B., Ortiz J.V., Cui Q., Baboul A. G., Clifford S., Cioslowski J., Stefanov B.B., Liu G., Liashenko A., Piskorz P., Komaromi I., Martin R.L., Fox D.J., Keith T., AlLaham M.A., Peng C.Y., Nanayakkara A., Challacombe M., Gill P.M.W., Johnson B., Chen W., Wong M.W., Gonzalez C. and Pople J.A. (2004) Gaussian 03, Revision C. 02, Gaussian, Inc., Wallingford, CT.

[14]Wei C.H. (1985) Acta. Crystallographica, C41, 1768-1770.

[15]Miessler G.L., Tarr D.A. (1999) Inorganic Chemistry, 2nd ed., Prentice-Hall Upper Saddle River, NJ, USA.

[16]Viswanadhan V.N., Ghose A.K., Revankar G.R., Robins R.K. (1989) Journal of Chemical Information and Computer Sciences, 29, 163-172.

[17]Ghose A.K., Crippen G.M. (1987) Journal of Chemical Information and Computer Science, 27, 21-35.

[18]Bodor N., Gabanyi Z., Wong C.K. (1989) Journal of the American Chemical Society, 111, 3783-3786.

[19]Gavezzotti A. (1983) Journal of the American Chemical Society, 105, 5220-5225.

[20]Miller K.J. (1990) Journal of the American Chemical Society, $112,8533-8542$.

[21]Ooi T., Oobatake M., Nemethy G., Scheraga H.A. (1987) Proceedings of the National Academy of Sciences of the USA, 84, 3086-3090.

[22]Prochaska H.J., Yeh Y., Baron P., Polsky B. (1993) Proceedings of the National Academy of Sciences of the USA, 90, 3953-3957.

[23]Kensler T.W., Groopman J.D., Sutter T.R., Curphey T.J., Roebuck B.D. (1999) Chemical Research in Toxicology, 12, 113-126.

[24]Bass S.E., Sienkiewicz P., MacDonald C.J., et al (2009) Clinical Cancer Research, 15, 1964-1972.

[25]Munday R., Zhang Y., Munday C.M., Li J. (2006) ChemicoBiological Interactions, 160, 115-122.

[26]Paonessa J.D., Munday C.M., Mhawech-Fauceglia P., Munday R., Zhang Y. (2009) Chemico-Biological Interactions, 180, 119126.

[27]Bae E.J., Yang Y.M., Kim J.W., Kim S.G. (2007) HEPATOLOGY, 46, 730-739.

[28]Pouzaud F., Christen M.O., Warnet J.M., Rat P. (2004) Pathologie Biologie, 52, 308-313.

[29]Lam S., MacAulay C., le Riche J.C., Dyachkova Y., Coldman A., Guillaud M., Hawk E., Christen M.O., Gazdar A.F. (2002) Journal of the National Cancer Institute, 94, 1001-1009.

[30]Maxuitenko Y.Y., Libby A.H., Joyner H.H., Curphey T.J., MacMillan D.L., Kensler T.W., Roebuck B.D. (1998) Carcinogenesis, 19, 1609-1615.
[31]Giannini F.A., Aimar M.L., Sortino M., Gomez R., Sturniollo A., Juarez A., Zacchino S., de Rossi R.H., Enriz R.D. (2004) IL FARMACO, 58, 245-254.

[32]Sang M.S., Sang G.K. (2009) Molecular Pharmacology, 75, 242-253.

[33]Belaidi S., Dibi A., Omari M. (2002) Turkish Journal of Chemistry, 26, 491-500.

[34]Belaidi S., Laabassi M., Gree R., Botrel A. (2003) Scientific Study \& Research, 4, 27-38.

[35]Belaidi S., Lanez T., Omari M., Botrel A. (2005) Asian Journal of Chemistry, 17, 859-870.

[36]Belaidi S., Omari M., Lanez T., Dibi A. (2004) Journal of the Algerian Society of Chemistry, 14, 27-39.

[37]Belaidi S., Laabassi M., Gree R., Botrel A. (2005) Revue Roumaine de Chimie, 50, 759-765.

[38]Belaidi S., Omari M., Lanez T. (2006) Annals of the Faculty of Sciences and Engineering Sciences, 1, 1-4.

[39]Belaidi S., Harkati D. (2011) ISRN Organic Chemistry, 594242.

[40]Kerns E.H., Di L. (2008) Drug-like Properties: Concepts, Structure Design and Methods: from ADME to Toxicity Optimization, Academic Press, USA, 43-47.

[41]Pliska V., Testa B., van de Waterbeemd H., Mannhold R., Kubinyi H., Timmerman H. (1996) Lipophilicity in Drug Action and Toxicology, Wiley-VCH, Federal Republic of Germany.

[42]Yavorski B., Detlaf A. (1980) Checklist of Physics, 376.

[43]TAMMO (1995) Theoretical Analysis of Molecular Membrane Organization, CRC Press, Boca Raton, Florida, USA.

[44]Deleu M. (2000) Synthesis of Surfactin Derivatives and Study Their Properties, Thesis Ph.D, FUSAGX, Belgique.

[45]Kier L.B. (1981) Molecular Orbital Theory in Drug Research, Academic Press, New York, NY, USA. 